\title{
PERLINDUNGAN HUKUM UMKM DARI EKSPLOITASI EKONOMI DALAM RANGKA PENINGKATAN KESEJAHTERAAN MASYARAKAT
}

\author{
(UMKM Legal Protection from Economic Exploitation to Improve Social Welfare)
}

\author{
Laurensius Arliman S \\ Sekolah Tinggi Ilmu Hukum Padang \\ Jalan Gang Mesjid Baiturahman Nomor 40, RT 02, RW 01, Lubuk Lintah, Padang \\ Email: laurensiusarliman@gmail.com
}

Naskah diterima: 19 Agustus 2017; revisi: 7 November 2017; disetujui: 8 November 2017

\begin{abstract}
Abstrak
Usaha Mikro Kecil dan Menengah (UMKM) memiliki peran strategis dalam memperkokoh perekonomian rakyat secara nasional, sehingga pemerintah harus memberi perhatian terhadap strategi dan kebijakan bagi pemberdayaan UMKM. Tulisan ini membahas problematika pengembangan UMKM dalam rangka peningkatan kesejahteraan masyarakat, bentuk-bentuk eksploitasi UMKM dan bentuk perlindungan hukum UMKM. Penelitian ini menggunakan metode yuridis nomatif dengan pendekatan deskriptif analitis. Hasil penelitian menunjukkan bahwa problematika pengembangan UMKM meliputi beberapa hal seperti kesulitan pemasaran, keterbatasan finansial, keterbatasan SDM, masalah bahan baku, dan keterbatasan teknologi. Sedangkan pola eksploitasi UMKM meliputi akumulasi modal, penciptaan ketergantungan secara ekonomi maupun secara sosial, dan struktur pasar yang monopolitis. Sampai saat ini, bentuk perlindungan hukum UMKM yang diberikan pemerintah adalah melalui penyederhanaan syarat dan tata cara permohonan izin usaha, tata cara pengembangan, pola kemitraan, penyelenggaraan koordinasi dan pengendalian pemberdayaan UMKM, serta tata cara pemberian sanksi administratif. Dari kesimpulan tersebut pemerintah direkomendasikan membuat pengaturan yang lebih lanjut, terkait perlindungan hukum UMKM, mengawasi pihak-pihak yang bermain curang, serta memberikan perlindungan hukum yang lebih baik bagi UMKM. Selain itu, negara seharusnya melakukan reformasi, salah satunya dengan memberikan bantuan hukum gratis untuk UMKM dan pemutihan pajak.
\end{abstract}

Kata Kunci: perlindungan hukum, UMKM, eksploitasi, kesejahteraan masyarakat

\begin{abstract}
Small and Medium Enterprises (UMKM) have strategic role to strengthen national economy, therefore government should pay attention to the strategies and policies developed to empowering UMKM. This paper discusses UMKM development problem in order to improve the welfare of the community, UMKM exploitation forms, and UMKM legal protection. This method used in this study is normative juridical with analytical descriptive approach. The research shows that UMKM development face several problems such as marketing difficulties, limited financial resources, limited human resources, raw material issues, and limited technology. In the other hand, UMKM exploitation may take many forms such as accumulation of capital, the creation of economic and social dependency, and a monopolistic market structure. Until now, government has given several legal protection for UMKM for instance the simplification of requirements and procedures for business permits application, development procedures, partnership pattern, organized coordination and control for UMKM empowerment, and administrative sanctions procedures. Referring to the conclusion, the government is recommended to regulate further some issues such as UMKM legal protection, supervision toward cheating parties and provide stronger legal protection for UMKM. The state is also entitled to conduct some reforms for instance by providing free legal assistance for UMKM and tax amnesty.
\end{abstract}

Keywords: legal protection, UMKM, exploitation, public welfare 


\section{A. Pendahuluan}

Pembangunan ekonomi nasional berdasarkan Pasal 33 ayat (1) Undang-Undang Dasar Negara Republik Indonesia Tahun 1945 (UUD 1945) bertujuan untuk meningkatkan kesejahteraan rakyat secara keseluruhan, bukan kesejahteraan orang-seorang atau kelompok dan golongan tertentu. Karena itu perekonomian nasional harus disusun sebagai usaha bersama berdasar atas asas kekeluargaan untuk mencapai kemakmuran dan kesejahteraan. Untuk mewujdukan kesejahteraan rakyat tersebut, dilakukan melalui berbagai upaya, yang salah satu upayanya adalah meningkatkan daya saing Usaha Mikro Kecil dan Menengah (UMKM) di Indonesia pada saat ini.

Peran UMKM memiliki nilai strategis dalam memperkokoh perekonomian nasional (ekonomi rakyat) maka selayaknya pemerintah memberi perhatian yang layak (strategi dan kebijakan) bagi pemberdayaan (prioritas dan pemihakan), yaitu dipandang sebagai suatu kelompok unit usaha yang seharusnya terintegrasi dalam dunia usaha secara nasional yang nantinya dapat meningkatkan tarif hidup dan daya saingnya. UMKM sebagai cikal bakal kewirausahaan yang berproses, perlu diberi perhatian yang lebih seksama dari berbagai aspek.

Sejak pergantian pemerintah orde baru dari orde lama, sampai dengan era reformasi, pembangunan perekonomian menjadi prioritas utama Pemerintah Indonesia. Keterbelakangan dan kemiskinan yang parah yang ditinggalkan oleh orde lama menjadi dasar kuatnya keinginan pemerintah orde baru untuk membangun perekonomian Indonesia sebagai sarana untuk menuju kemajuan dan kesejahteraan masyarakat, hal itu juga diwujudkan dalam pemerintahan era reformasi. Proses industrialisasi sebagaimana yang pernah dilakukan oleh negara maju dan dipercaya dapat membawa terobosan yang cepat dilaksanakan, dengan harapan masyarakat pertanian tradisional Indonesia secara bertahap menjadi masyarakat industri yang modern. ${ }^{1}$

Keadaan tersebut bagi perusahaan telah menimbulkan karakter untuk berkembang dengan cepat tanpa melalui proses alamiah, melainkan dengan memanfaatkan berbagai fasilitas pemerintah serta perilaku bisnis yang tidak sehat. Upaya lain yang dilakukan oleh perusahaan adalah dengan mencari modal asing melalui pinjaman komersial yang beresiko tinggi dalam bentuk commercial paper. Pinjaman tersebut juga dilakukan dengan sistem nilai tukar yang mengambang. Upaya untuk memacu pertumbuhan yang bertumpu pada pengusaha besar telah mengakibatkan pengusaha menengah dan kecil menjadi terabaikan, padahal secara kuantitas perusahaan-perusahaan tersebut jauh lebih besar dan mencakup lebih banyak rakyat. ${ }^{2}$

Proses perubahan pembangunan ekonomi, secara simultan diikuti oleh pembentukan dan perubahan kebijakan, regulasi berikut kelembagaan, dan mekanisme implementasi yang mengakomodasi perkembangan perekonomian Indonesia. Besarnya arus pengaruh ekonomi terhadap perubahan dan pembentukan hukum di Indonesia telah secara 
alami membentuk hukum ekonomi tersendiri. Bidang ini kemudian secara berkesinambungan mendapat perhatian para pembuat kebijakan di Indonesia, sejak pertumbuhan ekonomi menjadi upaya pembangunan nasional. ${ }^{3}$ Ini menunjukkan perkembangan ekonomi sebelum terjadinya krisis di Indonesia sangat berkembang, dan kebijakan hukum yang dikeluarkan pemerintah juga membantu perekonomian.

Kebijakan yang lebih terfokus kepada pencapaian target pertumbuhan (economic growth) telah mengakibatkan pemerintah lebih mengutamakan perkembangan perusahaan besar dengan tujuan untuk menghasilkan devisa. Kebijakan tersebut dilaksanakan dengan asumsi bahwa pertumbuhan nantinya dengan sendirinya akan melahirkan pemerataan kesejahteraan bagi rakyat, sesuai dengan teori tricle down effect. ${ }^{4}$

Problematika UMKM menyangkut sejumlah persoalan, seperti ketimpangan struktural dalam alokasi dan penguasaan sumber daya, ketidaktegasan keberpihakan negara pada upaya pengembangan ekonomi rakyat dalam kebijakan dan pengembangan strategi industrialisasi, struktur pasar yang bersifat oligopolis, kinerja yang relatif terbatas pada hal yang klasikal (sumber daya manusia atau SDM, permodalan dan akses terhadap kelembagaan keuangan, teknologi, manajemen, pemasaran dan informasi), ${ }^{5}$ terjadinya distorsi dan inkonsistensi kebijakan yang menyangkut upaya pengembangan.
Thee Kian Wie ${ }^{6}$ menyatakan bahwa UMKM kini telah banyak diimplementasikan di Indonesia, hal ini didasarkan atas pertimbangan pemerataan atau kesejahteraan ketimbang pertimbangan efisiensi. Rupanya pertimbangan pemerataan ini melihat UMKM sebagai usaha yang lemah dan tidak mempunyai prospek baik untuk berkembang menjadi usaha yang efisien dan mempunyai daya hidup ekonomi (economy viabilty) yang baik. Namun karena pertimbagan pemerataan, usaha-usaha kecil ini wajib dibantu. Di sisi lain Thhe Kian Wie juga menyatakan pertimbangan efisiensi dalam program promosi UMKM menekankan bahwa banyak usaha kecil dapat berkembang menjadi usaha yang efisien dan berdaya saing tinggi, jika diberikan bantuan yang tepat guna (appropriate) bagi mereka. Pendekatan ini melihat bahwa program-program promosi usaha kecil di masa lampau lebih bersifat pogram top-down atau supply-driven, yaitu program bantuan yang lebih banyak ditentukan oleh pemerintah, tanpa benar-benar memperhatikan kebutuhan rill UMKM untuk meningkatkan kesejahteraan masyarakat. $^{7}$

Seharusnya keberhasilan UMKM keluar dari krisis ekonomi di Indonesia, dapat dilihat sebagai bukti bahwa UMKM lebih mandiri dalam kegiatan ekonomi, karena mampu berusaha tanpa didukung pihak lain. Hal ini tampak dari modal dan teknologi yang dipakai adalah milik sendiri. Kemandirian usaha penting bagi para pelaku ekonomi untuk mampu bersaing

Ibid, hlm. 220.

Yoserwan, Op.cit, hlm. 93.

Musa Hubeis, Prospek Usaha Kecil Dalam Wadah Inkubator Bisnis, (Bogor: Ghalia Indonesia, 2015), hlm. 1-2. Thee Kian Wie, Prolog, dalam Nurul Widyaningrum, et-al, Pola-Pola Eksploitasi Terhadap Usaha Kecil, (Yogyakarta: Yayasan Akatiga, 2003), hlm. v.

7 Ibid. 
dengan usaha lain dalam merebut pasar. Betapa pentingnya UMKM dalam kegiatan perekonomian nasional, kiranya tidak dapat diragukan lagi dengan adanya pemikiran sejak lama yang menyatakan binis usaha kecil rakyat sangat penting. Namun yang terjadi pada hari ini UMKM sepertinya tereksploitasi dengan aturan-aturan oleh kepentingan para pihak yang ingin menguntungkan diri sendiri, adanya perusahaan besar ataupun pengumpul yang bisa siap memainkan harga mereka di pasaran dan hal lain sebagainya yang akan diuraikan dalam tulisan ini.

Berdasarkan latar belakang di atas, maka penelitian ini dimaksudkan untuk menjawab permasalahan sebagai berikut: 1) Bagaimana problematika pengembangan UMKM dalam rangka peningkatan kesejahteraan masyarakat? 2) Bagaimanakah bentuk-bentuk eksploitasi UMKM? Dan 3) Bagaimana perlindungan hukum UMKM dalam rangka peningkatan kesejahteraan masyarakat?

\section{B. Metode Penelitian}

Penelitian hukum yang dilaksanakan merupakan penelitian hukum normatif dengan metode pendekatan yuridis normatif yang menitikberatkan penggunaan bahan atau materi penelitian data sekunder dengan di dukung oleh data kepustakaan. Di samping itu, penelitian ini juga menggunakan pendekatan perundangundangan (statute approach), pendekatan historis (historical approach), dan pendekatan perbandingan (comparative approach). ${ }^{8}$ Dilihat dari spesifikasinya, penelitian ini termasuk deskriptif analitis yaitu penelitian yang menggabarkan dan menganalisis permasalahan yang berhubungan dengan perlindungan hukum UMKM dalam rangka peningkatan kesejahteraan masyarakat. Dalam penelitian ini, proses perolehan data untuk menunjang hasil penelitian dilakukan melalui tahapan studi kepustkaan (library research) dengan menggunakan data sekunder, yaitu mencoba untuk menemukan buku-buku, konsep-konsep, teori-teori dan pendapat para ahli serta penemuan yang berhubungan erat dengan pokok permasalahan yang akan menganalisis (1) problematika pengembangan UMKM dalam rangka peningkatan kesejahteraan masyarakat; (2) bentuk-bentuk eksploitasi UMKM yang terjadi pada hari ini dan (3) perlindungan hukum UMKM dalam rangka peningkatan kesejahteraan masyarakat.

\section{Pembahasan}

\section{Problematika Pengembangan UMKM Dalam Rangka Peningkatan Kesejah- teraan Masyarakat}

Posisi usaha kecil di dalam perekonomian Indonesia menjadi semakin penting, terutama setelah krisis melanda Indonesia. Krisis telah membuktikan bahwa daya tahan UMKM lebih tangguh bila dibandingkan dengan kebanyakan usaha besar. Selain itu pemerataan akan lebih efektif melalui pengembangan usaha kecil karena jumlahnya yang besar dan sifatnya yang umumnya padat karya. Alasan lain adalah dengan adanya kondisi seperti sekarang ini, investasi yang masih bisa berjalan adalah

8 Johnny Ibrahim, Teori dan Metodologi Penelitian Hukum Normatif, (Malang: Bayu Media Publishing, 2006), hlm. 302 . 
investasi pada sektor-sektor yang pekerjaannya banyak dilakukan oleh UMKM, seperti tekstil dan garmen, kerajinan, atau pertanian. ${ }^{9}$ Meskipun perhatian kepada usaha kecil bukanlah hal yang baru di dalam kebijakan pemerintahan Indonesia, sampai saat ini pengembangannya belum terasa benar-benar efektif.

Musa Hubeis menyatakan permasalahan, peluang dan pengembangan UMKM dalam ekonomi nasional maupun global menunjukan hal-hal apa yang perlu diperkuat dalam percaturan bisnis (mampu atau tidak bertahan) dan usaha-usaha begaimanakah yang perlu dikembangkan di masa-masa mendatang, dalam rangka mencapai perspektif UMKM yang potensial dan dinamis. Hal tersebut, terutama permasalahannya dikelompokkan atas 3 (tiga) kategori berikut: ${ }^{10}$ (1) permasalahan klasik dan mendasar, misalnya keterbatasan modal, SDM, pengembangan produk dan akses pemasaran; (2) permasalahan pada umumnya, misalnya antara peran dan fungsi instansi terkait dalam menyelesaikan masalah dasaryang berhubungan dengan masalah-masalah lanjutan, seperti prosedur perizinan, perpajakan, agunan dan hukum; (3) permasalahan lanjutan, misalnya pengenalan dan penetrasi pasar ekspor yang belum optimal, kurangnya pemahaman desain produk yang sesuai dengan karaker pasar, permasalahan hukum yang menyangkut perzinan, hak paten dan prosedur kontrak.

Problematika pengembangan UMKM dalam rangka peningkatan kesejahteraan masyarakat tersebut bisa dijelaskan oleh 7 (tujuh) faktor atau karakteristik berikut ini: ${ }^{11}$
(1) Kesulitan pemasaran. Salah satu aspek yang terkait dengan masalah pemasaran yang umum dihadapi oleh UMKM adalah tekanan-tekanan persaingan, baik di pasar domestik dari produk-produk serupa buatan usaha besar, maupun produk impor dan di pasar ekspor;

(2) Keterbatasan finansial. UMKM dalam menghadapi dua masalah utama dalam aspek finansial, yaitu mobilisasi modal awal dan akses ke modal kerja investasi, serta finansial jangka panjang akibat skala ekonomi yang kecil. Modal yang dimiliki oleh pengusaha kecil sering kali tidak mencukupi untuk kegiatan produksinya, terutama investasi (perluasan kapasitas produksi atau penggantian mesin-mesin tua) walaupun pada umumnya modal awal bersumber dari modal sendiri atau sumber-sumber informal;

(3) Keterbatasan SDM. Keterbatasan SDM merupakan salah satu kendala serius UMKM, terutama dalam aspek-aspek kewirausahaan, manajemen, teknik produksi, pengembangan produk, perancangan teknik, akuntansi, pengolahan data, penelitian, dan teknik pemasaran. Semua keahlian ini sangat dibutuhkan untuk mempertahankan dan/atau memperbaiki mutu produk, meningkatkan efisiensi dan produktivitas dalam produksi, memperluas pangsa pasar dan menembus pasar baru;

(4) Masalah bahan baku. Keterbatasan bahan baku dan masukan lainnya sering menjadi salah satu kendala serius bagi pertumbuhan dan kelangsungan produksi bagi banyak UMKM atau sentra-sentra UMKM di

\footnotetext{
9 Nurul Widyaningrum, Op.cit, hlm. XI.

10 Musa Hubeis, Op.cit, hlm. 4.

11 Ibid, hlm. 4-10.
} 
sejumlah sebsektor industri manufaktur, seperti sepatu dan produksi tekstil yang mengalami kesulitan untuk mendapatkan bahan baku atau masukan, akibat depresiasi nilai tukar mata uang rupiah terhadap mata uang asing (misalnya dolar, euro atau yuen);

(5) Keterbatasan teknologi. UMKM masih menggunakan teknologi dalam bentuk mesin-mesin tua (manual). Keterbelakangan teknologi ini tidak hanya menyebabkan rendahnya total faktor produktivitas dan efiensi di dalam proses produksi, tetapi juga rendahnya mutu produk yang dibuat. Keterbatasan teknologi UMKM disebabkan oleh banyak faktor, di antaranya keterbatasan modal investasi untuk membeli mesinmesin baru guna menyempurnakan proses produksi, keterbatasan informasi mengenai perkembangan tekonologi (mesin-mesin dan alat-alat produksi baru), serta keterbatasan SDM yang dapat mengoperasikan mesinmesin baru dan melakukan inovasi-inovasi dalam produk maupun proses produksi;

(6) Kekurangmampuan pengusaha kecil untuk menentukan pola manajemen yang sesuai dengan kebutuhan dan tahap perkembangan usahanya, sehingga pengelolaan usaha menjadi terbatas. Dalam hal ini, manajemen merupakan seni yang dapat digunakan atau diterapkan dalam penyelenggaraan kegiatan apapun, karena dalam setiap kegiatan akan terdapat unsur perencanaan, pelaksanaan dan pengawasan. Atas dasar hal tersebut, maka praktik-praktik manajemen dapat dilakukan berbagai bidang ataupun fungsi yang ada dalam suatu usaha, yaitu sebagai berikut: a) planning (perencanaan); ${ }^{12}$ b) organizing (pengorganisasian); ${ }^{13} \quad$ c) actuating (pelaksanaan); ${ }^{14}$ d) controlling (pengawasan); ${ }^{15}$

(7) Kemitraan. Kemitraan mengacu pada pengertian bekerja sama antar-pengusaha dengan tingkatan yang berbeda, yaitu antara pengusaha kecil dengan pengusaha besar. Istilah kemitraan sendiri mengandung arti bahwa meskipun tingkatannya berbeda, hubungan yang terjadi merupakan hubungan yang setara (sebagai mitra), bukan bentuk hubungan yang merupakan manifestasi hubungan patron-klien.

Atas problematika diatas, masih banyak pihak meragukan UMKM dalam perannya mensejahterakan masyarakat. Pandangan orang yang mengecilkan dan skeptis terhadap keberadaan usaha kecil menghadapi tata dunia baru dalam era globalisasi ekonomi berupa ekonomi pasar bebas, sehingga timbul keraguan akan kemampuan usaha kecil untuk membangkitkan dan memulihkan kembali

12 Planning (perencanaan) adalah perhitungan dan penentuan tentang apa yang akan dijelaskan dalam rangka mencapai suatu tujuan tertentu dari suatu organisasi atau perusahaan; dimana, bilamana, oleh siapa, dan bagaiamana tata cara yang harus dilakukan untuk mencapai tujuan tersebut.

13 Organizing (pengorganisasian) adalah suatu tindakan yang dilakukan untuk memikirkan, memperhitungkan dan menyediakan segala sesuatunya, untuk membuka suatu kemungkinan, agar rencana yang telah ditentukan sebelumnya dapat dilaksanakan dengan baik.

14 Actuating (pelaksanaan) adalah fungsi manajemen yang merupakan penggabungan dari beberapa fungsi manajemen lain. Dalam praktik, fungsi actuating dilaksanakan dalam bentuk lima subfungsi manajemen, yaitu komunikasi, kepemimpinan, pengarahan atau penjelasan, memotivasi, serta penyediaan sarana dan kemudahan.

15 Controlling (pengawasan) adalah keseluruhan kegiatan yang membandingkan atau mengukur apa yang sedang atau sudah dilaksanakan dengan kriteria, standar atau rencana-rencana yangtelah ditetapkan sebelumnya. 
kegiatan ekonomi nasional. Sikap skeptis lain adalah perputaran uang pada usaha kecil relatif lambat dalam kegiatan bisnis yang bersaing ketat dibandingkan usaha besar. Pandangan skeptis ini justru akan menyulitkan terciptanya keadilan sosial sebagaimana yang diharapkan bersama. ${ }^{16}$ Keraguan tersebut timbul, karena belum dipahami keberadaan usaha kecil dalam kegiatan ekonomi nasional selain adanya anggapan kuat bahwa era globalisasi ekonomi membutuhkan pelaku usaha setingkat konglomerasi yang andal dan mampu bersaing di tingkat pasar nasional, regional dan internasional. Di samping itu terdapat anggapan bahwa, pelaku bisnis dari usaha kecil ini sulit untuk dapat menerima budaya persaingan. ${ }^{17}$ Peran pemerintah dibutuhkan untuk menggenjot perkembangan jenis usaha UMKM dalam persaingan usaha bisnis dan globalisasi ekonomi yang semakin ketat.

Upaya pemberdayaan terhadap UMKM adalah peningkatan aspek permodalan, kebebasan pasar dan penguasaan teknologi oleh pemerintah, dunia usaha dan masyarakat dengan mengubah orientasi politik-ekonomi yang mendasar. ${ }^{18}$ Kebijakan pemberdayaan ini seharusnya berpihak pada perekonomian rakyat dalam tindakan nyata untuk dapat mengejar ketinggalan UMKM dalam persiangan usaha dan pasar bebas. ${ }^{19}$ Menurut Teguh Sulistia pemberdayaan UMKM memiliki arti penting dalam pengembangan ekonomi nasional dan perannya dalam mensejahterakan masyarakat, karena: (1) UMKM termasuk dalam pilar pembangunan ekonomi yang dibina dan dilindungi oleh pemerintah; (2) usaha kecil mempunyai potensi untuk berkembang sehingga sanggup terjun ke arena ekonomi global dan (3) adanya ketangguhan dan kemandirian usaha, ekonomi rakyat ini mempunyai prospek dalam persaingan pasar bebas kelak. ${ }^{20}$

Apabila problematika dalam pengembangan UMKM berhasil diatasi, maka kesejahteraan rakyat akan semakin terjamin. Hal ini tentu tidak terlepas dari pandangan secara filosofis, cita dan cita-cita sosial yang dikehendaki oleh UUD 1945, di mana tujuan dari pembangunan ekonomi adalah menciptakan keadilan sosial bagi seluruh rakyat Indonesia. Cita dan cita-cita sosial UUD 1945 bertumpu pada dua prinsip pokok, yaitu:21 1) prinsip demokrasi ekonomi atau social economicshe democratis akan mengedepankan prinsip-prinsip demokrasi dalam perkembangan ekonomi di Indonesia dan 2) prinsip yang mengacu pada HAM (hak asasi manusia), prinsip ini menurut UUD 1945 tidak hanya berdimensi politik tetapi juga mengedapankan nilai-nilai HAM yang bersifat

16 Yuli Rahmini Suci, “Perkembangan UMKM (Usaha Mikro Kecil dan Menengah Di Indonesia)" Cano Ekonomos, Vol. 6. No. 1, (Januari, 2017): 51-58.

17 Teguh Sulistia, Aspek Hukum Usaha Kecil Dalam Ekonomi Kerakyatan, (Padang: Andalas University Press, 2006), hlm. 4.

18 Roswita Hafni dan Ahmad Rozali, "Analisis Usaha Mikro, Kecil dan Menengah (UMKM) Terhadap Penyerapan Tenaga Kerja Di Indonesia", Vol. 15. No. 2. (2015): 77-96.

19 Revrisond Baswir, "Keterbelakangan Usaha Kecil dan Peningkatan Otonomi Daerah", Jurnal Analisis Sosial, Vol. 5, No. 1, (Januari 2000): 7.

20 Teguh Sulistia, Pengaturan Usaha Kecil Dalam Ekonomi Kerakyatan, Disertasi, (Surabaya, Pascasarjana Universitas Airlangga, 2006), hlm. 35.

21 Ade Komarudin, Politik Hukum Integratif UMKM, Kebijakan Negara Membuat UMKM Maju dan Berdaya Saing, (Jakarta: PT Semesta Rakyat Merdeka, 2014), hlm. 92. 
sosial-ekonomi. Karena itu makna dari keadilan sosial, kesejahteraan umum, dan kemakmuran rakyat bukan sekedar fenomena sosial atau ekonomi, melainkan sebagai fenomena demokrasi dan HAM.

\section{Bentuk-Bentuk Eksploitasi UMKM}

UMKM sangat berfungsi dalam memajukan perekonomian nasional, hal ini dilihat dari Kontribusi UMKM dalam menyerap tenaga kerja sangat besar. Di balik potensi tersebut, terdapat beberapa faktor yang menghambat pengembangan UMKM, bahkan hal ini menjadi salah satu cara untuk mengeksploitasi UMKM untuk kepentingan segelintir orang yang ingin memiliki banyak untung. Faktor-faktor eksploitasi tersebut di antaranya dipengaruhi dengan kurangnya modal, kemampuan manajemen, kemampuan sumber daya manusia, termasuk juga kelemahan dalam sistem produksi, yang busa dimanfaatkan orang yang tidak bertanggung jawab. Pengusaha UMKM juga sering menghadapi kesulitan jika bersentuhan dengan masalah hukum. ${ }^{22}$ Berikut penulis akan mencoba menyajikan bentukbentuk eksploitasi UMKM tersebut.

Akumulasi modal merupakan ukuran yang digunakan untuk melihat proses yang menandai berkembang atau tidaknya suatu unit usaha. Di dalam UMKM, pengertian akumulasi modal tersebut tidak hanya diukur dari adanya peningkatan skala usaha tetapi juga dapat dilihat melalui adanya peningkatan kesejahteraan bangsa. Hanya saja perlu diamati apakah bentuk-bentuk peningkatan usaha maupun kesejahteraan keluarga tersebut merupakan sumbangan dari usaha yang bersangkutan ataukah disebabkan adanya subsidi dari pendapatan lainnya. Secara umum UMKM tidak dapat mengakumulasi modal dibandingkan pelaku-pelaku usaha lainnya yang lebih besar di jalur penyediaan bahan baku, jalur pemasaran produk, dan jalur pemodalan. Terdapat pola relasi yang mengeksploitasi kelompok-kelompok pelaku UMKM. Pada setiap pelaku usaha di dalam rantai komoditas dan pola-pola eksploitatif yang menjadi penyebab adanya perbedaan kemampuan akumulasi modal tersebut. ${ }^{23}$

Rantai hulu hilir UMKM terdapat hubungan eksploitatif yang menyebabkan sekelompok pelaku UMKM tidak dapat mengakumulasi modal. Relasi eksploitatif dapat terjadi ketika sekelompok orang atau pelaku memiliki kekuasaan atau privilege yang lebih besar dibandingkan pihak lain, sehingga pelaku yang bersangkutan dapat menentukan aturan main dan kondisi hubungan yang menguntungkan dirinya sendiri. Ketimpangan kekuasaan tersebut kemudian cenderung dimanfaatkan untuk mengeksploitasi usaha yang lemah. Bagaimana kekuasaan ini diwujudkan dalam membangun aturan main serta kondisi hubungan yang menguntungkan pelaku eksploitasi serta dari mana kekuasaan ini diperoleh merupakan pertanyaan klasik yang tidak terjawab sampai pada hari ini.

Nurul Widyaningrum menyatakan terdapat 2 (dua) pola eksploitasi yang terjadi pada rantai hulu hilir UMKM. Pola pertama adalah eksploitasi yang terjadi terhadap kelompok lebih miskin melalui penciptaan ketergantungan

22 Ni Luh Ristha Ariani dan Made Suksuma Prijandhini Devi Salain, "Perlindungan Hukum Bagi Usaha Mikro, Kecil Dan Menengah (UMKM) Yang Berbentuk Bukan Perseroan Terbatas (PT)", Jurnal Kerthasemaya, (2015): 2.

23 Nurul Widyaningrum, Op.cit, hlm. 19. 
secara ekonomi maupun secara sosial. Kemiskinan dan kerentanan kelompok UMKM salah satunya ditandai oleh ketidakcukupan pendapatan mereka dari satu sumber penghasilan saja untuk memenuhi kebutuhan sehari-hari. Ketidakcukupan pendapatan ini yang kemudian menyebabkan rumah tangga UMKM harus mencari sumber penghasilan lain di luar usaha yang digeluti oleh mereka. Selain itu, ketidakcukupan penghasilan tersebut juga membuat rumah tangga itu tidak memiliki tabungan maupun bentuk investasi yang dapat digunakan sebagai cadangan dihari-hari mendatang pada saat terjadi guncangan dalam rumah tangga mereka, sehingga harus mencari tambahan penghasilan maupun pinjaman untuk dapat menutupi pengeluaran ekstra tersebut. ${ }^{24}$

Kondisi ketidakcukupan pendapatan tersebutlah yang ditangkap oleh pelaku-pelaku lain dan dimanfaatkan untuk menciptakan ketergantungan secara ekonomi dan sosial. Pada umumnya pelaku yang memanfaatkan kondisi ini adalah kelompok pedagang perantara yang berada di desa atau kecamatan yang sama dengan kelompok UMKM. Meskipun sebutan untuk kelompok pedagang ini berbeda-beda di wilayah yang berbeda, peranan yang mereka mainkan sama, yaitu menjadi pengumpul produk kelompok-kelompok UMKM lalu menyalurkan ke pasar yang lebih luas. Mekanisme yang ditempuh kelompok pedagang perantara untuk membangun keterikatan dengan kelompok UMKM adalah membangun utang serta membangun jalur perdagangan berlapis dengan menjadi pemasok kebutuhan seharihari begi kelompok UMKM. ${ }^{25}$ Selain penciptaan ketergantungan melalui mekanisme utang dan perdagangan berlapis, para pedagang perantara tersebut juga memanfaatkan relasi sosial yang terjalin di antara mereka. Relasi sosial yang mewarnai hubungan perdagangan yang terlibat cukup kental adalah hubungan kekerabatan di antara kelompok UMKM. Hubungan sosial yang melapisi hubungan ekonomi ini menyebabkan upaya-upaya memutuskan pola relasi eksploitatif antara pengumpul dengan kelompok UMKM sulit dilakukan. Faktor rasa tidak enak untuk melepaskan diri dari pengumpul, hal ini menjadi faktor yang cukup penting dalam hubungan-hubungan perdagangan dan pemasaran UMKM. ${ }^{27}$

Sementara pola kedua adalah pola eksploitasi yang terjadi melalui penciptaan struktur pasar yang monopolitis (penjual tunggal) atau monopsonistis (pembeli tunggal) atau penuh dengan perilaku mafia, sehingga terjadi penekanan melalui mekanisme penentuan harga dan penyediaan barang secara sepihak. Monopoli dan perilaku mafia yang ada pada rantai perdagangan ditandai dengan adanya sekelompok pelaku yang menguasai jalur pengangkutan produk serta hubungan yang erat dengan pelaku pasar akhir yang menyebabkan pelaku lain sulit untuk masuk. ${ }^{27}$ Monopoli jalur perdagangan menyebabkan pelaku-pelaku pada jalur tersebut dapat menentukan aturan

Ibid, hlm. 84.

Ibid, hlm. 89.

26 Ibid, hal ini juga disampaikan Suparyono, Anggit Wicaksono dan Wiwit Ariyani, "Model Pemberdayaan Usaha Mikro Kecil dan Menengah (UMKM) Melalui Program Corporate Social Responsibility (CSR) Pada Industri Rokok Di Kudus" Jurnal Sosial Budaya, Vol. 6, No. 2, (Desember, 2013): 29-39.

27 Nurul Widyaningrum, Op.cit, hlm. 92. 
main terutama dalam hal harga serta kondisi pembayaran.

Pada rantai perdagangan antarpulau dan antarwilayah, penentu aturan main serta kondisi dagang terutama berada di tangan-tangan aktor-aktor yang bertindak sebagai mafia. Para mafia ini melakukan kesepakatan-kesepakatan dengan pihak-pihak pedagang lintas wliayah untuk menjamin keamanan para pedagang tersebut melakukan kegiatannya dengan menerima imbalan, mereka juga menjaga agar kegiatan perdagangan tersebut sulit dimasuki pemain baru. Aturan-aturan main di dalam perdagangan antara pedagang antarwilayah dengan pembeli di wilayah lain ditentukan oleh pelaku mafia tersebut. ${ }^{28}$

Rantai pemasaran yang monopolistis dalam perdagangan karya UMKM menyebabkan eksploitasi berjenjang dari para pedagang di tingkat kecamatan ke kelompok pedagang perantara di bawahnya (tingkat desa). Pedagang pengumpul di desa membangun hubungan eksploitatif dengan kelompok pengrajin melalui mekanisme utang dan perdagangan kebutuhan sehari-hari. Interaksi-interaksi sosial yang dimanfaatkan secara negatif oleh kelompok pedagang menambah kuat eksploitasi yang terjadi antara pengumpul dengan pemilik UMKM. Kuatnya hubungan eksploitatif tersebut menyebabkan upaya yang bertujuan untuk memotong rantai perdagangan relatif belum berhasil.

\section{Perlindungan Hukum UMKM Dalam Rangka Peningkatan Kesejahteraan Masyarakat}

Usaha kecil sebagai bagian integral dari dunia usaha merupakan kegiatan ekonomi rakyat yang mempunyai kedudukan, potensi dan peran yang strategis untuk mewujudkan struktur perekonomian nasional yang makin seimbang berdasarkan demokrasi ekonomi sebagai amanat dari Pasal 33 UUD 1945. Upaya ke arah itu harus dilakukan dengan sepenuh hati melalui penataan kelembagaan di tingkat yang lebih operasional dan teknis secara sistematis. Dukungan politis yang konsisten dan nyata di berbagai tingkatan sangat diperlukan dalam mengembangkan ekonomi rakyat ini. Ekonomi rakyat adalah sistem yang berbasis pada kekuatan ekonomi rakyat sesuai Pasal 33 ayat (1) UUD 1945 dan Sila Keempat Pancasila. Artinya rakyat harus berpartisipasi penuh secara demokratis dalam menentukan kebijaksanaan ekonomi dan tidak menyerahkan begitu saja keputusan ekonomi pada kekuatan atau mekanisme pasar. ${ }^{29}$

Perkembangan usaha rakyat tidak akan terlepas dari persoalan politik, ekonomi dan hukum. Persoalan politik berkaitan dengan praktik kehidupan berbangsa dan negara oleh pemerintah demokrasi, persoalan ekonomi dalam upaya menata dan meningkatkan kesejahteraan rakyat melalui kegiatan ekonomi yang baik serta persoalan hukum untuk mencapai tujuan nasional yang dicita-citakan. Semua saling bersinergi (berkaitan) dalam segenap aspek persoalan bangsa dan negara

Ibid, hlm. 95-98.

Julius Bobo, Transformasi Ekonomi Rakyat, (Jakarta: Cidesindo, 2003), hlm. 93. 
yang mengalami reformasi menuju masa depan yang lebih baik.

Melihat begitu hegemoniknya proses liberisasi ekonomi, maka diperlukan perlindungan agar UMKM tetap berkembang dan memilki daya saing. Kurangnya perlindungan hukum terhadap UMKM, membuat UMKM Indonesia mengalami kesulitan dalam berkembang. ${ }^{30}$ Sayangnya, fakta tersebut seringkali malah disalahpahami Pemerintah, dunia usaha dan masyarakat. Modal yang terbatas, kualitas SDM, kelemahan penguasaan teknologi malah dilihat sebagai kekurangan UMKM, ketimbang dilihat sebagai akibat yang timbul dari tidak adanya perlindungan (protection) dan pemberdayaan (empowerment) yang memadai. ${ }^{31}$ Padahal, siapapun tahu jika kebijakan politk pemerintah secara makro seringkali salah arah dan tidak tepat sasaran dan kurang melindungi UMKM dari persaingan bisnis.

Apabila UMKM tidak diberikan perlindungan hukum oleh pemerintah, maka dapat dipastikan UMKM tidak dapat berkembang. Dalam arti bahwa usaha kecil tidak dapat berkembang dalam posisi berdiri dama tinggi, duduk sama rendah, dengan usaha yang jauh lebih besar. Perlindungan menjadi kata kunci penting bagi usaha kecil, mengingat tantangan liberalisasi ekonomi yang semakin besar. Prinsip perlindungan dalam hukum ekonomi terutama kegiatan UMKM adalah mencakup: ${ }^{32}$

(1) Prinsip ekonomi dalam UUD 1945, prinsip ini seperti dirumuskan oleh the founding father atau pembentuk UUD 1945 yang telah memikirkan dengan matang bangunan ekonomi bagi bangsa Indonesia, melalui prinsip ekonomi guna mencapai tujuan nasional yaitu masyarakat adil dan makmur. Artinya kemakmuran rakyat dapat diperoleh melalui kegiatan ekonomi yang betulbetul sehat dan jauh dari praktik-praktik persaingan usaha tidak sehat. Apabila diperhatikan dengan seksama, ada 7 (tujuh) asas prinsip ekonomi yang dimuat dalam Pasal 33 UUD 1945, yaitu: ${ }^{33}$ keseimbangan, keserasian dan keselarasan, persamaan, usaha bersama, kekeluargaan, musyawarah untuk mufakat (demokrasi ekonomi), manfaat, perlindungan dan pembinaan pihak yang lemah;

(2) Prinsip perlindungan kepentingan nasional. Ketentuan dalam Pasal 33 ayat (2) dan (3) UUD 1945 diatur mengenai penguasaan negara atas cabang-cabang produksi yang memenuhi kepentingan nasional. Penguasaan sebagai bentul daripada kepentingan nasional. Penguasaan negara atas cabang-cabang produksi tersebut didasarkan pada upaya untuk dapat melindungi kepentingan rakyat banyak guna memenuhi kebutuhan primer dan perilaku pengusaha tidak baik yang menguasai sumber daya di dalam bentuk monopoli. Perlu dikemukakan bahwa prinsip perlindungan kepentingan nasional yang ditetapkan berarti ada kepentingan umum

\footnotetext{
30 Ari Ratna Kurniastuti, "Perlindungan Hukum Usaha Mikro Kecil Menengah (Umkm) Dari Dampak Adanya Perjanjian Asean-China Free Trade Area (Acfta)", Jurnal Arena Hukum, Vol. 6, No. 2, (April, 2013): 184-203.

31 Sukarmi, "Perlindungan Sosial Desain Industri Bagi UMKM Yang Berkeadilan Sosial”, Jurnal Pembaharuan Hukum, Vol. 3, No. 1 (April, 2016): 97-108.

32 Ade Komarudin, Op.cit, hlm. 20-21.

33 Jimly Asshiddiqie, Konstitusi Ekonomi, (Jakarta: Kompas Media Nusantara, 2010), hlm. 282.
} 
yang tidak boleh bersifat kontraproduktif terhadap asas kebebasan berkontrak. Artinya demi kepentingan umum dan nasional, ruang gerak kebebasan berkontrak bagi para pelaku usaha tidak semakin sempit dalam kegiatan bisnis. Apabila ini terjadi, sama saja tidak ada pengakuan negara terhadap asas kebebasan berkontrak, sekalipun untuk perlindungan kepentingan umum/nasional, karena mematikan pengusaha dalam berbisnis;

(3) Prinsip perlindungan dalam hukum internasional dan hukum perdata. Selain aspek hukum nasional yang berupaya meningkatkan kemampuan daya saing produk barang dan jasa dalam negeri, perekonomian nasional juga harus memperhatikan prinsip perlindungan hukum internasional. Perlindungan ini akan mempengaruhi reputasi ekonomi dan perlakuan negara lain terhadap kegiatan pemasaran produk-produk Indonesia, baik di dalam maupun luar negeri. Perlindungan hukum internasional dan hukum perdata internasional dalam kerangka perdagangan antar negara melalui pelbagai sarana transportasi dan komunikasi saling menghormati berdasarkan perjanjian internasional dan prinsip pacta sunt servanda, yaitu perjanjian yang telah disepakati berlaku sebagai undangundang bagi pihak yang menyelenggarakan perjanjian;

(4) Prinsip perlindungan bagi golongan ekonomi lemah. Berbagai ketentuan yang mengatur pengembangan UMKM selama ini menunjukkan perhatian pemerintah terhadap pengusaha kecil. Di antara ketentuan tersebut adalah Undang-Undang Nomor 9 tahun 1995 tentang Usaha Kecil juncto Undang-Undang Nomor 20 tahun 2008 tentang Usaha Mikro Kecil dan Menengah sebagai upaya perlindungan hukum untuk pengusaha kecil, sehingga pembinaan pasar bagi usaha kecil harus merupakan suatu sistem terpadu, karena pengembangannya tergantung dari interaksi unsur organisasi dari para pengusaha kecil dan komponen pendukung dari kebijakan eknomi pemerintah, usaha menengah dan usaha besar yang dapat saling membantu dan mempengaruhi;

(5) Prinsip perlindungan kepentingan nasional dalam GATT. Kepentingan ekonomi nasional suatu negara perlu dilindungi dari praktik bisnis curang, baik yang dilakukan oleh pengusaha di dalam negeri maupun pengusaha asing. Begitu juga oleh negara industri maju terhadap negara berkembang melalui kebijakan ekonomi yang dapat menghalangi masuknya barang ekspor dan impor ke negara tersebut. Prinsip dan perlindungan kepentingan nasional ini tetap diakui di dalam ketentuan GATT sebagai bentuk pengecualian dari prinsip umum terhadap industri dan negara tertentu pada kegiatan ekonomi dunia; ${ }^{34}$

(6) Prinsip persaingan usaha yang sehat. Kegiatan bisnis modern yang ketat dan penuh persaingan menimbulkan perlakuan kurang adil dan sering dialami oleh pihak ekonomi lemah. Pengusaha yang kuat dan

34 Murad Purba, "Pengaruh Ketentuan Internasional Tentang Hambatan Teknis Perdagangan (Technical Barriers to Trade) terhadap Hukum Nasional", Jurnal Majalah Hukum Nasional, No. 2, (1998): 102. 
serakah dengan berbagai cara berusaha untuk menguasai pasar nasional, regional dan internasional. Praktik curang tidak hanya dilakukan berdasarkan perbuatan melawan hukum (onrechtmatige daad) dalam hukum perdata, ${ }^{45}$ akan tetapi juga berupa penyalahgunaan hak yang merugikan bagi pengusaha dan negara-negara berkembang mengekspor produk berupa bahan mentah, barang setengah jadi atau kerajinan. Bentuk persaingan curang (unfair competition) tidak dapat ditolerir dan perlu dicegah dan dikurangi di dalam kegiatan bisnis, baik melalui peraturan perundang-undangan maupun dalam bentuk putusan hakim dan kebijakan ekonomi pejabat eksekutif. Klausula kontrak bisnis yang curang secara nyata melahirkan keuntungan tidak wajar atau tidak sebanding besarnya pada satu pihak. Sebaliknya, pihak-pihak yang lain karena ketidaktahuan atau kelemahan tertentu yang dihadapinya semakin terdesak kedudukan ekonominya dalam angka persaingan pasar; ${ }^{46}$

Berdasarkan kebijakan yang ada, maka yang terpenting adalah penciptaan iklim usaha kecil. Hal ini dirumuskan Pasal 8 huruf G Undang-Undang Nomor 9 Tahun 1995 tentang Usaha Kecil dan Undang-Undang Nomor 20 Tahun 2008 tentang Usaha Mikro, Kecil, dan Menengah yang dilakukan melalui penetapan peraturan perundang-undangan dan kebijakan perlindungan bagi ekonomi lemah. Namun dalam undang-undang tersebut tidak ditegaskan tentang bentuk peraturan perundang-udangan yang harus dikeluarkan untuk dapat mengatur dan melaksanakan lebih lanjut mengenai perlindungan yang harus diberikan kepada UMKM. $^{47}$

Atas dasar hal tersebut bentuk-bentuk perlindungan hukum UMKM dalam rangka mensejahterkan masyarakat yang harus dilakukan oleh pemerintah adalah sebagai berikut: ${ }^{48}$

(1) syarat dan tata cara permohonan izin usaha yang lebih dipermudah agar UMKM dapat lebih cepat bersaing untuk melakukan usaha nya, selama ini yang terjadi UMKM kesulitan mendapatkan atau dikeluarkan izin usaha;

(2) tata cara pengembangan, pengembangan UMKM harus lebih digiatkan. Hal ini tentu saja dengan peran dari pemerintah untuk mendukung pengembangan UMKM, hal ini bisa dimulai dengan peningkatan SDM sehingga meningkatkan mutu dan kulitas dari hasil UMKM tersebut;

(3) prioritas, UMKM harus menjadi prioritas pemerintah, hal ini dilihat sewaktu krisis moneter yang terjadi di Indonesia, UMKM mampu tetap tumbuh dan berkembang sampai dengan sekarang;

(4) intensitas dan jangka waktu pengembangan, intensitas dari bisnis UMKM harus memiliki roadmap yang jelas serta capaian yang pasti setiap semesternya, selain itu waktu pengembangan harus semakin dipacu, hal ini untuk membuat UMKM semakin

\footnotetext{
Munir Fuady, Perbuatan Melawan Hukum, Citra Aditya Bakti, Jakarta, 2010, hlm. 64.

Teguh Sulistia, Op.cit, hlm.127

7 Ade Komarudin, Op.cit, hlm. 23.

38 Dhaniswara K. Harjono, UMKM Butuh Perlindungan Hukum Dalam Menghadapi MEA, http://www.hukumonline. com/berita/baca/lt54291034f072b/umkm-butuh-perlindungan-hukum-dalam-menghadapi-mea-2015, (diakses 17 Agutus 2017).
} 
kokoh di dalam perannya mensejahterakan masyarakat;

(5) pola kemitraan, UMKM harus memiliki pola kemitaraan dalam memasarkan produknya, sehingga kegiatan output UMKM jelas dan terarah serta mampu bersaing di pasar nasional ataupun pasar kelas mancanegara;

(6) penyelenggaraan kordinasidan pengendalian pemberdayaan UMKM, koordinasi dan pengendalian pemberdayaan UMKM dari pusat ke daerah dan sebaliknya dari pusat ke daerah harus jelas dan berimbang, aturanaturan yang ada seharusnya menguntungkan UMKM, bukan menjadikan UMKM semakin merugi karena aturan-aturan yang membuat mereka kesulitan; dan

(7) tata cara pemberian sanksi administratif, harus diatur tata cara pemberian sanksi administratif bagi UMKM yang bertindak curang atau bahkan adanya perusahaan besar yang memomopoli pasar, sehingga UMKM tidak mampu memasarkan barang dagangannya.

Selain itu menyangkut keadilan, kepastian hukum, dan manfaat. Negara seharusnya melakukan sesuatu yang sifatnya reformasi, salah satunya dengan memberikan bantuan hukum gratis untuk UMKM dan pemutihan pajak. Hal ini mengingat hukum tidak hanya berperan untuk menjamin adanya kepastian dan ketertiban semata, sebagaimana halnya konsep Negara penjaga malam. Akan tetapi hukum juga harus berfungsi untuk mempercepat proses pembangunan nasional. ${ }^{39}$ Menurut Mochtar
Kusumaatmadja, hukum diharapkan berfungsi lebih daripada sekedar itu, yakni dapat sebagai sarana pembaharuan masyarakat atau sarana pembangunan dengan pokok-pokok pikiran sebagai berikut:40 hukum merupakan sarana pembaharuan masyarakat didasarkan kepada anggapan bahwa adanya keteraturan atau ketertiban dalam usaha pembangunan dan pembaharuan itu merupakan suatu yang diinginkan atau dipandang (mutlak) perlu.

\section{Penutup}

Pembangunan ekonomi nasional berdasarkan Konstitusi bertujuan untuk meningkatkan kesejahteraan rakyat secara keseluruhan. Peran UMKM memiliki nilai strategi dalam memperkokoh perekonomian rakyat secara nasional, maka selayaknya pemerintah memberi perhatian yang layak, terhadap strategi dan kebijakan bagi pemberdayaan, prioritas dan pemihakan kepada UMKM. Problematika pengembangan UMKM dalam rangka peningkatan kesejahteraan masyarakat tersebut bisa dijelaskan oleh 7 (tujuh) faktor, yaitu: Kesulitan pemasaran; Keterbatasan finansial; Keterbatasan SDM; Masalah bahan baku; Keterbatasan teknologi; Kekurangmampuan pengusaha kecil untuk menentukan pola manajemen yang sesuai dengan kebutuhan dan tahap perkembangan usahanya; dan Kemitraan. Jika kita berhasil untuk mengatasi problematik dalam pengembangan UMKM untuk kesejahteraan rakyat, maka secara filosofis, cita dan cita-cita sosial yang dikehendaki oleh UUD 1945 adalah menciptakan keadilan sosial bagi

39 Yusri, "Perlindungan Hukum Terhadap Usaha Mikro, Kecil dan Menengah Dalam Perspektif Keadilan Ekonomi", Kanun Jurnal Ilmu Hukum, No. 62, Th. XVI, (April 2014): 122.

40 Mochtar Kusumaatmadja, Hukum, Masyarakat, dan Pembinaan Hukum Nasional, (Bandung: Binacipta, 1995), hlm.13. 
seluruh rakyat Indonesia. Sedangkan secara sosial-ekonomi, cita dan cita-cita sosial tersebut adalah terwujudnya kesejahteraan umum untuk sebesar-besarnya kemakmuran rakyat.

Terdapat 2 (dua) pola eksploitasi yang terjadi pada rantai hulu hilir UMKM. Pola pertama adalah eksploitasi yang terjadi terhadap kelompok lebih miskin melalui penciptaan ketergantungan secara ekonomi maupun secara sosial. Kemiskinan dan kerentanan kelompok UMKM salah satunya ditandai oleh ketidakcukupan pendapatan mereka dari satu sumber penghasilan saja untuk memenuhi kebutuhan sehari-hari. Sementara pola kedua adalah pola eksploitasi yang terjadi melalui penciptaan struktur pasar yang monopolitis (penjual tunggal) atau monopsonistis (pembeli tunggal) atau penuh dengan perilaku mafia, sehingga terjadi penekanan melalui mekanisme penentuan harga dan penyediaan barang secara sepihak.

Atas dasar hal tersebut maka diperlukan perlindungan agar UMKM tetap berkembang dan memiliki daya saing. Perlindungan hukum bagi UMKM dalam menghadapi liberalisasi ekonomi tersebut memiliki arti yang sangat penting. Prinsip perlindungan dalam hukum ekonomi terutama kegiatan UMKM adalah mencakup: Prinsip ekonomi dalam UUD 1945; Prinsip perlindungan kepentingan nasional; Prinsip perlindungan dalam hukum internasional dan hukum perdata; Prinsip perlindungan bagi dolongan ekonomi lemah; Prinsip perlindungan kepentingan nasional dalam GATT; dan Prinsip persaingan usaha yang sehat. Untuk mendukung prinsip tersebut maka pemerintah harus melakukan tindakan sebagai berikut: syarat dan tata cara permohonan izin usaha yang lebih dipermudah; tata cara pengembangan; prioritas; intensitas dan jangka waktu pengembangan; pola kemitraan; penyelenggaraan kordinasi dan pengendalian pemberdayaan UMKM; dan tata cara pemberian sanksi administratif. Sehingga memberikan rasa nyaman dan perlindungan bagi pengembangan UMKM di Indonesia.

Guna memberikan perlindungan hukum tehadap UMKM dari eksploitasi ekonomi dalam rangka peningkatan kesejahteraan masyarakat, maka diperlukan langkah-langkah sebagai berikut: Pemerintah harus membuat pengaturan yang lebih lanjut terkait pemberian perlindungan UMKM dalam rangka peningkatan kesejahteraan masyarakat, dimana pemerintah harus mengundang pihak-pihak yang terkait untuk membuat pengaturan bisnis UMKM menjadi lebih baik lagi dan memberikan kepastian kepada pemilik UMKM di Indonesia demi menunjangkan kesejahteraan nasional. Pemerintah harus mengawasi pihak-pihak yang bermain curang, sehingga merugikan pelaku UMKM di Indonesia, selain itu pemerintah harus memberikan pelatihan, penyuluhan hukum, sosialisasi kepada masyarakat, agar masyarakat mendapatkan edukasi yang lebih baik dalam proses pengembangan UMKM di Indonesia. Pemerintah dan bersama LSM serta pihak-pihak yang terkait di dalam pembangunan UMKM harus memberik perlindungan hukum bagi UMKM dalam rangka peningkatan kesejahteraan masyarakat, sehingga masyarakat merasa terjamin dari segi hukum dan bantuan hukum dalam pengembangan UMKM.

\section{Daftar Pustaka}

\section{Buku}

Asshiddiqie, Jimly, Konstitusi Ekonomi, (Jakarta: Kompas Media Nusantara, 2010).

Bobo, Julius, Transformasi Ekonomi Rakyat, (Jakarta: Cidesindo, 2003).

Fuady, Munir, Perbuatan Melawan Hukum, Citra Aditya Bakti, Jakarta, 2010. 
Hubeis, Musa, Prospek Usaha Kecil Dalam Wadah Inkubator Bisnis, (Bogor: Ghalia Indonesia, 2015).

Ibrahim, Johnny, Teori dan Metodologi Penelitian Hukum Normatif, (Malang: Bayu Media Publishing, 2006).

Komarudin, Ade, Politik Hukum Integratif UMKM, Kebijakan Negara Membuat UMKM Maju dan Berdaya Saing, (Jakarta: PT Semesta Rakyat Merdeka, 2014).

Kusumaatmadja, Mochtar, Hukum, Masyarakat, dan Pembinaan Hukum Nasional, (Bandung: Binacipta, 1995).

Sulistia, Teguh, Aspek Hukum Usaha Kecil Dalam Ekonomi Kerakyatan, (Padang: Andalas University Press, 2006).

SS, Kusumanigtuti, Peranan Hukum dalam Penyelesaian Krisis Perbankan di Indonesia, (Jakarta: Rajawali Press, 2009).

Yoserwan, Hukum Ekonomi Indonesia, Dalam Era Reformasi dan Globalisasi, (Padang: Andalas University Press, 2006).

Wie, Thhe Kian, Prolog, dalam Nurul Widyaningrum, et-al, Pola-Pola Eksploitasi Terhadap Usaha Kecil, (Yogyakarta: Yayasan Akatiga, 2003).

\section{Makalah/Artikel/Laporan/Hasil Penelitian}

Ariani, Ni Luh Ristha dan Made Suksuma Prijandhini Devi Salain, "Perlindungan Hukum Bagi Usaha Mikro, Kecil Dan Menengah (UMKM) Yang Berbentuk Bukan Perseroan Terbatas (PT)", Jurnal Kerthasemaya, (2015).

Baswir, Revrisond, "Keterbelakangan Usaha Kecil dan Peningkatan Otonomi Daerah", Jurnal Analisis Sosial, Vol. 5, No. 1, (Januari 2000).

Hafni, Roswita dan Ahmad Rozali, "Analisis Usaha Mikro, Kecil dan Menengah (UMKM) Terhadap
Penyerapan Tenaga Kerja Di Indonesia", Vol. 15. No. 2. (2015).

Harjono, Dhaniswara K. UMKM Butuh Perlindungan Hukum Dalam Menghadapi MEA, http:// www.hukumonline.com/berita/baca/ It54291034f072b/umkm-butuh-perlindunganhukum-dalam-menghadapi-mea-2015, (diakses 17 Agutus 2017).

Kurniastuti, Ari Ratna, "Perlindungan Hukum Usaha Mikro Kecil Menengah (Umkm) Dari Dampak Adanya Perjanjian Asean-China Free Trade Area (Acfta)", Jurnal Arena Hukum, Vol. 6, No. 2, (April, 2013).

Purba, Murad, "Pengaruh Ketentuan Internasional Tentang Hambatan Teknis Perdagangan (Technical Barriers to Trade) terhadap Hukum Nasional", Jurnal Majalah Hukum Nasional, No. 2, (1998).

Suci, Yuli Rahmini, "Perkembangan UMKM (Usaha Mikro Kecil dan Menengah Di Indonesia)" Cano Ekonomos, Vol. 6. No. 1, (Januari, 2017).

Sukarmi, "Perlindungan Sosial Desain Industri Bagi UMKM Yang Berkeadilan Sosial", Jurnal Pembaharuan Hukum, Vol. 3, No. 1 (April, 2016).

Sulistia, Teguh, Pengaturan Usaha Kecil Dalam Ekonomi Kerakyatan, Disertasi, (Surabaya, Pascasarjana Universitas Airlangga, 2006).

Suparyono, Anggit Wicaksono dan Wiwit Ariyani, "Model Pemberdayaan Usaha Mikro Kecil dan Menengah (UMKM) Melalui Program Corporate Social Responsibility (CSR) Pada Industri Rokok Di Kudus" Jurnal Sosial Budaya, Vol. 6, No. 2, (Desember, 2013).

Yusri, "Perlindungan Hukum Terhadap Usaha Mikro, Kecil dan Menengah Dalam Perspektif Keadilan Ekonomi", Kanun Jurnal Ilmu Hukum, No. 62, Th. XVI, (April 2014). 